\title{
Akrep Hemolenfinin Kanser Hücrelerinde Antiproliferatif ve Morfolojik Etkilerinin Araştırılması
}

\author{
Arzu İşcan ${ }^{1,2}$, Figen Çalışkan ${ }^{1,3}$, Hatice Mehtap Kutlu ${ }^{4, *}$, Canan Vejselova Sezer ${ }^{4}$, Hakan \\ Çalışkan $^{3}$
}

Geliş / Received: $31 / 01 / 2020$

Revize / Revised: $12 / 03 / 2020$

Kabul / Accepted: 13/03/2020

ÖZ

Buthidae familyasına ait Anadolu sarı akrebi olarak bilinen Mesobuthus gibbosus (Brullé, 1832) ülkemizde geniş bir dağılım gösterir ve bu nedenle halk sağlığı açısından önemli bir türdür. Bu çalışmada Mesobuthus gibbosus hemolenfinin A549 akciğer kanseri hücre hattı ve Beas-2B normal akciğer epitel hücre hattı üzerindeki sitotoksik etkisini belirlemek amacı ile MTT testi uygulanmıştır. Hücresel değişiklikler morfolojik olarak konfokal mikroskop ve geçirimli elektron mikroskop ile araştırılmıştır. Hemolenfin A549 akciğer kanseri ve Beas-2B normal akciğer epitel hücre hatları ile 24 saat süresince inkübasyonu sonucu doza bağlı olarak $\mathrm{IC}_{50}$ değerleri, A549 hücreleri için \%1.35, Beas-2B hücreleri için ise \%1.34 olarak belirlenmiştir. Konfokal mikroskopi ile her iki hücre için hücrelerde yuvarlaklaşma, membran tomurcuklanması, hücre çekirdeğinde kromatin yoğunlaşması görüntülenmiştir. Elektron mikroskopi ile hücre şekli bozulması, büzülme, hücre iskeletinde yırtıklar ve lizozom oluşumu, hücre zarlı organellerinde mitokondri kristalarında kayıp ve şişmeler görüntülenmiştir. Bu çalışma ile Mesobuthus gibbosus hemolenfinin her iki hücre hattı için de doza bağlı olarak antiproliferatif ve apoptotik etkileri bildirilmektedir.

Anahtar Kelimeler- Mesobuthus gibbosus, akrep, hemolenf, A549, Beas-2B, akciğer kanseri

\footnotetext{
3*Sorumlu yazar e-mail: hmkutlu@eskisehir.edu.tr (https://orcid.org/0000-0002-8816-1487)

${ }^{4}$ Eskişsehir Teknik Üniversitesi, Fen Fakültesi, Biyoloji Bölümü, Eskişehir, Türkiye

1E-mail: arzuiscan26@gmail.com (https://orcid.org/0000-0003-2366-2114)

${ }^{1}$ Eskişehir Osmangazi Üniversitesi, Fen Bilimleri Enstitüsü, Biyoteknoloji ve Biyogüvenlik ABD, Eskişehir, Türkiye

${ }^{2}$ Anadolu Üniversitesi, Bitki, İlaç ve Bilimsel Araștırmalar Uygulama ve Araştırma Merkezi (AÜBİBAM)

Yunus Emre Kampüsü, Eskişehir, Türkiye

2E-mail: fcalis@ogu.edu.tr (https://orcid.org/0000-0001-5241-7770)

${ }^{1}$ Eskişehir Osmangazi Üniversitesi, Fen Bilimleri Enstitüsü, Biyoteknoloji ve Biyogüvenlik ABD, Eskişehir, Türkiye

${ }^{3}$ Eskişehir Osmangazi Üniversitesi, Fen Edebiyat Fakültesi, Biyoloji Bölümü, Eskişehir, Türkiye

4E-mail: cananveyselova@gmail.com (https://orcid.org/0000-0002-3792-5993)

${ }^{4}$ Eskişehir Teknik Üniversitesi, Fen Fakültesi, Biyoloji Bölümü, Eskişehir, Türkiye

5E-mail: hakan@ogu.edu.tr (https://orcid.org/0000-0001-7879-6449)

${ }^{3}$ Eskişehir Osmangazi Üniversitesi, Fen Edebiyat Fakültesi, Biyoloji Bölümü, Eskişehir, Türkiye
} 


\title{
Investigation of Antiproliferative and Morphological Effects of Scorpion Hemolymph on Cancer Cells
}

\begin{abstract}
Mesobuthus gibbosus (Brullé, 1832), known as Anatolian yellow scorpion belonging to the Buthidae family, has a wide distribution in our country and is therefore an important species in terms of public health. In this study, MTT test was performed to determine the cytotoxic effect of Mesobuthus gibbosus hemolymph on A549 lung cancer cell line and Beas-2B normal lung epithelial cell line. Ultrastructural changes were investigated morphologically by confocal microscope and transmission electron microscope. $\mathrm{IC}_{50}$ values were determined as $1.35 \%$ for A549 cells and $1.34 \%$ for Beas-2B cells as a result of 24 hours incubation with hemolymph A549 lung cancer and Beas-2B normal lung epithelial cell lines. In the study performed with confocal microscopy, rounding in the cells, membrane budding, chromatin condensation in the cell nucleus were displayed for both cells. The results obtained by electron microscopy showed distortion of the cell shape, shrinkage, deformations and lysosome formation, loss and swelling on cristae of mitochondria. With this study, dose depended antiproliferative and apoptotic effects of Mesobuthus gibbosus hemolymph in both cell lines are reported.
\end{abstract}




\section{GİRIŞ}

Akrepler 20 farklı familyaya ait 2415 farklı tür olarak tanımlanan ve yeryüzünde kutup bölgeleri ile bazı adalar haricinde kalan geniş bir coğrafyaya dağılım gösteren canlılardır [1]. Akreplerin ölümcül zehirlenmeye yol açan biyoaktif bir kompleks karışımdan oluşan zehirleri bulunmaktadır. Bu zehirler farmakolojik ve fizyolojik etkinlikteki mukus, inorganik tuzlar, düşük molekül ağırlıklı organik moleküller, enzimler, peptidler, nükleotidler, lipidler, monosakkaritler, biyojenik aminler ve halen tanımlanmamış olan pek çok farklı molekülleri içeren kompleks karışımlardır [2,3]. Akreplerin ölümcül zehirlenmelere neden olduğu biliniyor olmasına karşın, aynı zamanda terapötik potansiyele sahip olmaları nedeniyle de binlerce yıl geleneksel tıp alanında kullanılmıştır. Günümüzde bu doğal karışım biyofarmasötik araştırmalarda yaygın olarak kullanılmaktadır [4]. Akrep zehirlerinin biyolojik etkinlikleri üzerine yapılmış pek çok araştırma bulunmaktadır. Ancak, zehir bezlerinde zehir üretimi dahil pek çok biyolojik ve metabolik aktivitelerini sağlayan hemolenfleri ile ilgili çalışmalar yok denecek kadar azdır. Oysaki biyolojik veya metabolik aktivite doğrudan hemolenf ile iliş̧ilidir ve ayrıca zehir bezinde üretilen zehirin de akreplerdeki hemolenf bileşimi ile doğrudan ilişkili olduğu bildirilmektedir. Hemolenf, akrep vücut ağırlığının \%34'ünü oluşturur ve vücut dışına çıktı̆̆ında pihtılaşmaz. Bileşiminde proteinler, serbest aminoasitler, karbohidratlar, lipitler ile sodyum, potasyum, kalsiyum, magnezyum, klor, bakır, demir, mangan ve çinko gibi iyonlar bulunmaktadır [5,6]. Androctonus australis türü akrebin hemolenfinden hem bakteri hem de mantarlara karşı etkin 25 aminoasit uzunluğunda Androctonin, 34 aminoasit uzunluğunda ise bir diğer antibakteriyal peptid Buthinin izole edilmiştir. Leiurus quinquestriatus türü akrebin hemolenfinden ise böceklerdeki defensine yüksek bir yapısal benzerlik gösteren akrep defensini izole edilmiş̧ir [7]. Son 10 yıl içerisinde akrep kökenli peptitlerin ister hemolenf ister venom kaynaklı olsun, izole edilip saflaştırılma çalışmaları artmıştır. Bunların özellikle çeşitli iyon kanallarını hedef almadaki nitelikleri ile etkileşimleri üzerine odaklanılmıştır. Akrep hemolenfi içerisinde de birçok polipeptid zinciri bulunmaktadır ve bu peptidlerle yapılan biyoaktif etkinlik çalışmalardan elde edilen sonuçlar umut vadetmekledir [8]. Kanser, dünya çapında yüksek sayıda ölüme yol açması nedeniyle önemli bir halk sağlığı sorunudur. Mevcut tedavi protokolleri halen tam yanıt vermemekte, yeni ve daha etkili antitümöral bileşiklerin keşfine ihtiyaç duyulmaktadır $[9,10]$. Akciğer kanseri dünya çapında kanserle ilişkili mortalitenin önde gelen nedenidir ve 3 temel akciğer kanseri türü vardır; küçük hücreli olmayan akciğer kanseri, küçük hücreli akciğer kanseri ve akciğer karsinoid tümörü. Küçük hücreli olmayan akciğer kanseri en sık görülen formdur ve akciğer kanseri tanılarının yaklaşık \%85'inden sorumludur [11]. Bu çalışma alternatif bir antitümoral doğal bileşen belirlenmesi amacıyla araştırılan Mesobuthus gibbosus hemolenfinin küçük hücreli olmayan A549 akciğer kanseri hücre hatt1 ve Beas-2B normal akciğer epitel hücre hattı üzerindeki antiproliferatif ve morfolojik etkilerini göstermektedir.

\section{DENEYSEL ÇALIŞMALAR}

\section{A. Hücre hatlarl ve kimyasallar}

A549 (ATCC $®$ CCL-185 ${ }^{\mathrm{TM}}$ ) akciğer kanser hücreleri ve Beas-2B ( ATCC $®$ \#CRL-9609 ${ }^{\mathrm{TM}}$ ) normal akciğer epitel hücre hattı Amerikan kültür koleksiyonu (ATCC ) Manassas, ABD'den, 3-(4,5-dimethylthiazol-2-yl)-2,5 diphenyl-2H-tetrazolium bromide (MTT), serum, penisilin-streptomisin, dimetil sülfoksit (DMSO) SigmaAldrich St. Louis, ABD'den temin edilmiş̧tir. Roswell Park Memorial Institute medium (RPMI-1640) GIBCO Grand Island, ABD'den satın alınmıştır. 


\section{B. Akreplerin Toplanması ve Bakımı}

Çalışmada kullanılan Mesobuthus gibbosus (Brullé, 1832) türü akrepler (Şekil 1) Sarıcakaya-Mihalgaziİnhisar yolu üzeri Eskişehir-Bilecik il sınırı civarından toplanmıştır. Akreplerin gece avlanan canlılar olmaları ve $365 \mathrm{~nm}$ UV dalga boyunda gösterdiği 1şımadan yararlanarak örnekler UV lamba ile gece toplanmışlardır. Toplanan akrepler temiz, hava alan kutular içerisinde Eskişehir Osmangazi Üniversitesi Venom Araştırma Laboratuvarına canlı olarak getirilmiş, oda ısısında su ve Telebrio molitor larvası ile desteklenerek haftalık bakımları yapılmıştır [12].
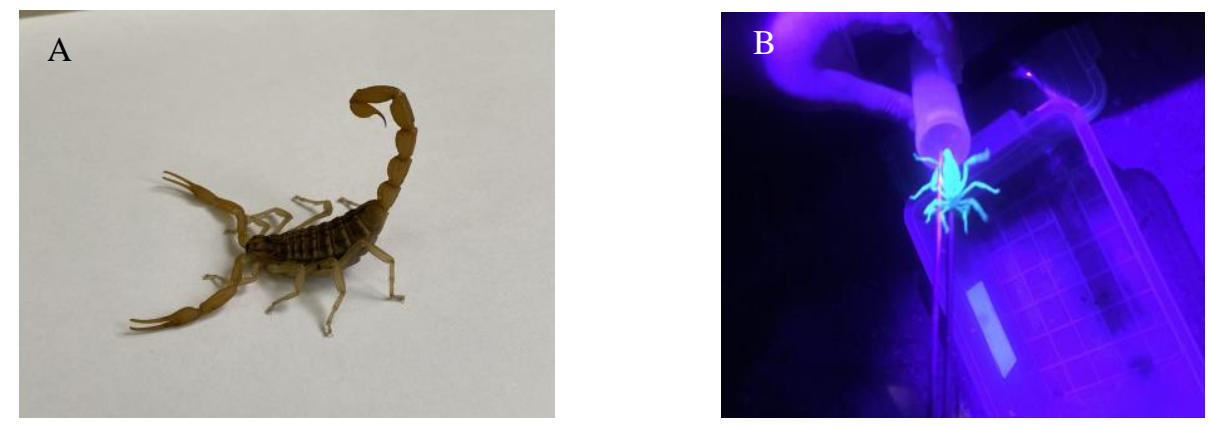

Şekil 1, A) Mesobuthus gibbosus türü akrebin gün ışığı ve B) Toplanma anı UV 1şığ1 altındaki görüntüsü

\section{Mesobuthus gibbosus Hemolenfin Elde Edilmesi}

Hemolenf eldesi öncesinde akreplerin beslenmesi yapılmayarak aç bırakılmışlardır. Anestezik olarak herhangi bir kimyasal kullanılmamış, $-20 \mathrm{C}^{0}$ 'de $7-8$ dak bekletildikten sonra temiz bir zemin üzerine sabitlenmiştir. Dorsal kısımın 7-13. segmentte bulunan boru şeklindeki kalplerinden delinmek suretiyle (Şekil 2A) dolaşım sistemindeki hemolenf enjektöre çekilmiştir. Toplam 5 akrepten elde edilen hemolenf (Şekil 2B) $5000 \mathrm{rpm}$ de, $10 \mathrm{dak},+4 \mathrm{C}^{0}$ 'de santrifüj edilmiştir. Süpernatan kısım sitotoksisite deneyleri ve ardından geçirimli elektron mikroskop (TEM) ve konfokal mikroskop ile gerçekleştirilecek morfolojik incelemeler için kullanılmak üzere $+4 C^{0}$ ' de ihtiyaç duyulan ana kadar saklanmıştır. Santrifüj sonrası tüpte kalan pelletler hemolenfin içerdiği hücresel kısım hemositler olarak adlandırılmış ve pellet halinde -20C ${ }^{0 ‘}$ de saklanmıştır [13,14].
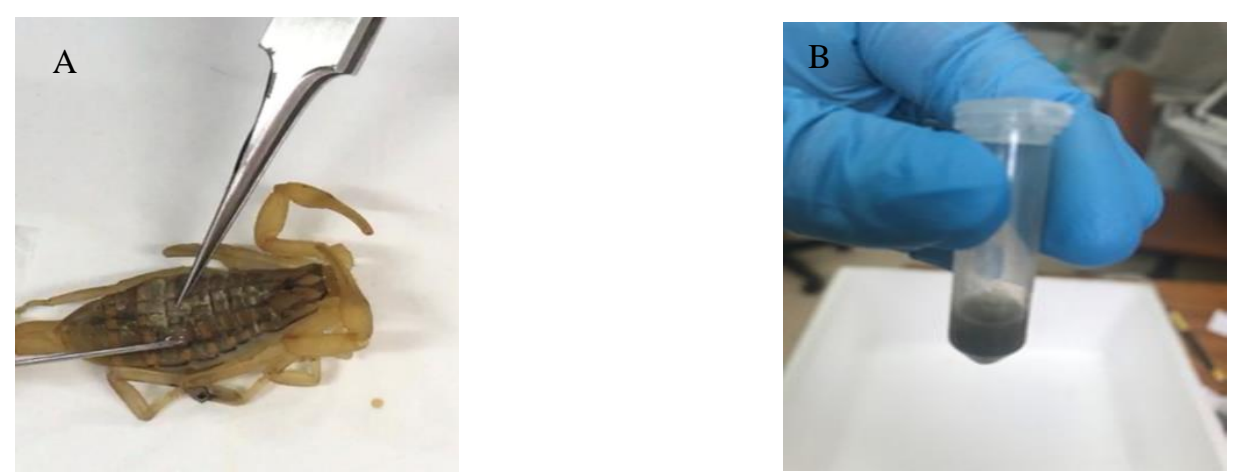

Şekil.2, Hemolenfin elde edilmesi, A; Kalbin delinmesi ile hemolenfin alınması. B; Mavi renkli hemolenfin genel görüntüsü. 


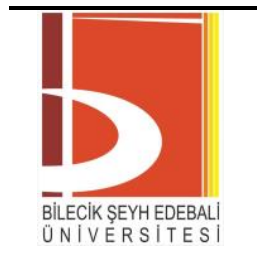

BŞEÜ Fen Bilimleri Dergisi

BSEU Journal of Science

7. Cilt - Milli Mücadele ve TBMM'nin

Açı1ışının 100. Yılı Anısına-100. Yıl Özel

Sayıs1

$363-372,2020$

e-ISSN: $2458-7575$ (http://dergipark.gov.tr/bseufbd)

\section{MTT Sitotoksisite Testi}

Hücre kısmı ayrılmış hemolenfin A549 akciğer kanseri ve Beas-2B normal akciğer epitel hücre hatları üzerindeki sitotoksisitesini belirlenemek için MTT [3-(4,5-dimetiltiazol-2-il)-2,5-difeniltetrazolium bromid] testi gerçekleştirilmiştir. Akreplerden elde edilen taze hemolenf, hücre hatlarının çoğaltıldığ 1 besiyeri olan RPMI1640 ortamında (\%10 FBS ve \%1 penisilin içeren) sırasıyla \%0.3125, \%0.625, \%1,25, \%2.5, \%5ve \%10 olacak şekilde seyreltilerek 96 kuyucuklu plakalara konulmuştur. Bu deneyde kuyu başına kullanılabilecek en yüksek doz olan \%10'luk seyreltmeden başlayarak dilüsyonlar hücrelere uygulanmıștır. Bunun üzerine A549 ve Beas2B hücreleri her kuyuda $5 \times 10^{3}$ yoğunlukta ekilerek 24 saat boyunca inkübatörde $\left(37^{\circ} \mathrm{C}\right.$ ve $\% 5$ karbondioksit) bekletilmiştir. Hem hücrenin adhere durumunu hem proliferatif etkiyi görmek için A549 ve Beas-2B hücreleri ile hazırlanmış hemolenf birlikte kuyucuklara konulmuştur. İnkübasyon sonunda, her kuyucuğa $20 \mu \mathrm{L}$ MTT boyası ilave edilerek 3 saat daha inkübasyonda bekletildikten sonra plaka içeriği boşaltılmıştır. Her kuyuya $100 \mu \mathrm{L}$ dimetil sülfoksit (DMSO) ilave edilerek plakalar eliza plaka okuyucuda (Biotek Synergy HTX) $570 \mathrm{~nm}$ dalga boyunda okutulmuştur. Elde edilen absorbanslardan canlllık yüzdeleri kontrolün verdiği absorbans miktarına göre hesaplanmıştır. Canlılık değerlerinden hemolenfin bu hücrelerin canlılığına etki eden dozun yarısı $\mathrm{IC}_{50}$ (Yarı maksimum inhibitör konsantrasyonu) değeri Microsoft Office Excel programı ile çizilen grafikten belirlenmiştir [15].

\section{E. Morfolojik değişikliklerin belirlenmesi}

Hücresel değişiklikler morfolojik olarak konfokal mikroskop ve geçirimli elektron mikroskop (TEM) ile araştırılmıştır. Konfokal mikroskopi için; A549 ve Beas-2B hücre hatlarına akrep hemolenfi IC $_{50}$ konsantrasyonunda uygulanmıştır. Hücreler 6 kuyucuklu plakaya 300x $10^{3}$ yoğunlukta olacak şekilde ekilmiş ve üzerlerine hemolenfin bu hücreler için elde edilen $\mathrm{IC}_{50}$ konsantrasyonu ilave edilerek $37^{\circ} \mathrm{C}$ de 24 saat süresince inkübe edilmiş̧ir. İnkübasyon sonunda hücreler akridin oranj ve falloidin boyaları ile boyanarak çekirdek ve hücre iskeleti yapısına bakılmıştır. Hücrelerdeki yapısal değişiklikler Leica TCS-SP5 II konfokal mikroskop kullanılarak Leica Confocal Software version 2.00 programı ile görüntülenmiştir [16 ].

İnce yapısal değişikliklerin tespiti için geçirimli elektron mikroskop kullanılarak, A549 ve Beas-2B hücre hatları üzerine önceden hazırlanmış akrep hemolenfinin $\mathrm{IC}_{50}$ konsantrasyonları verilmiştir. TEM analizleri için A549 ve Beas-2B hücreleri $75 \mathrm{~cm}^{2}$ lik flasklarda $37^{\circ} \mathrm{C}$ de 24 saat süresince inkübe edilmiștir. Sonrasında kaldırılan hücreler 1200 rpm'de 5 dakika santrifüj edilmiştir ve glutaraldehit ile fikse edilmiştir. İkinci fiksasyon olan osmiyum tetroksit içerisinde yarım saat bekletildikten sonra dehidratasyon (\%70, \%90, \%96 etil alkol) yapılmışıı ve en son saf etanolde (\%100) dehidrate edilmiştir. Propilen oksit ile şaffaflandırma gerçekleştirildikten sonra EPON 812 epoxy resine gömülen hücrelerin ultramikrotom (Leica EM UC6) ile 100 $\mathrm{nm}$ ince kesitleri alınmıştır. Kesitler kurşun sitrat ve uranil asetat ile boyandıktan sonra Tecnai TM G2 Spirit 120 $\mathrm{kV}$ mikroskobunda görüntülenmiş̧ir [17].

\section{F. Istatistiksel Analiz}

Deney sonuçlarından elde edilen verilerin anlamlılıkları GraphPad Prism 6.0 programının Two way ANOVA testinin Tukey post testi kullanılmış ve anlamlılık değeri $p<0,05$ olan veriler dikkate alınmıştır.

\section{DENEYSEL SONUÇLAR}

\section{A. MTT Sitotoksisite Sonuçları}

Mesobuthus gibbosus hemolenfinin farklı dozları ile 24 saat inkübe edilen A549 ve Beas-2B hücre hatlarının doza bağlı değişen \% canlılık oranı Çizelge 1 ile aşağıda verilmiştir. Microsoft Office Excel programı ile hesaplanan $\mathrm{IC}_{50}$ değerleri Beas-2B hücreleri için \%1.34, A549 hücreleri için ise $\% 1.35$ olarak tespit edilmiştir. 


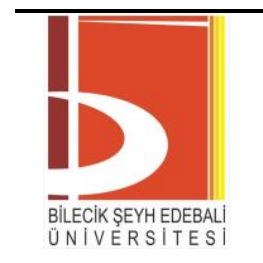

BŞEÜ Fen Bilimleri Dergisi

BSEU Journal of Science

7. Cilt - Milli Mücadele ve TBMM'nin

DOI: 10.35193/bseufbd.682149

Açılışının 100. Yılı Anısına-100. Yıl Özel

Sayıs1

363-372, 2020

e-ISSN: 2458-7575 (http://dergipark.gov.tr/bseufbd)

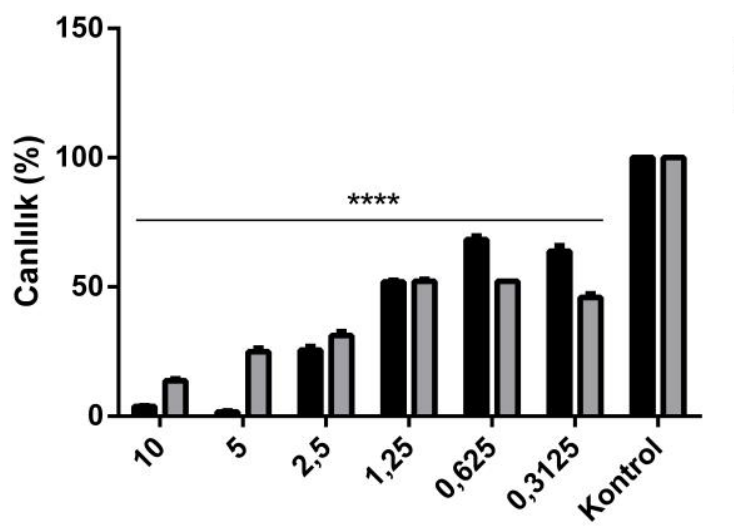

A549

Beas-2B

Dozlar (\%)

Çizelge 1. Hazırlanan hemolenfin A549 akciğer kanseri ve Beas-2B normal akciğer epitel hücrelerine 24 saat süresince doza bağlı olarak yüzde canlılık değerleri. (****: $p<0,0001$ )

\section{B. Konfokal Mikroskobu Sonuçları}

A549 ve Beas-2B hücre hatları $\mathrm{IC}_{50}$ konsantrasyonlarında 24 saat boyunca muamele edilmiștir. Akridin oranj ve falloidin ile boyandıktan sonra elde edilen konfokal görüntülerinden kontrol grubu olarak kabul edilen Beas-2B hücreleri ile hazırlanan hemolenf uygulanan Beas-2B deney grubu hücreler görüntülenmiştir (Şekil 3A ve 3B). Hemolenf ile muamele edilmemiş kontrol grubu A549 hücreleri ve $\mathrm{IC}_{50}$ değeri ile muamele edilen deney grubu A549 hücrelerinden görüntüler elde edilmiștir ( Sekil 4A ve 4B). Beas-2B normal akciğer epitel hücreleri kontrol ve deney grubu morfolojik olarak kıyaslandığında çok büyük bir deformasyon görülmemiştir. Hücreler mekik şeklindeki görüntülerini korumuşlardır. Yer yer hücre iskeletinde yırtıklar gözlenmiştir (Şekil 3B). Ancak A549 akciğer kanser hücrelerinin kontrol ve deney grupları karşılaş̧ırıldığında belirgin morfolojik değişiklikler gözlenmiștir. Hemolenf ile muamele edilmiș hücrelerde kromatin yoğunlaşması, hücre iskeleti üzerindeki delikler ve büzülmeden dolayı dairesel hücre şekilleri görülmüştür (Şekil 4B).
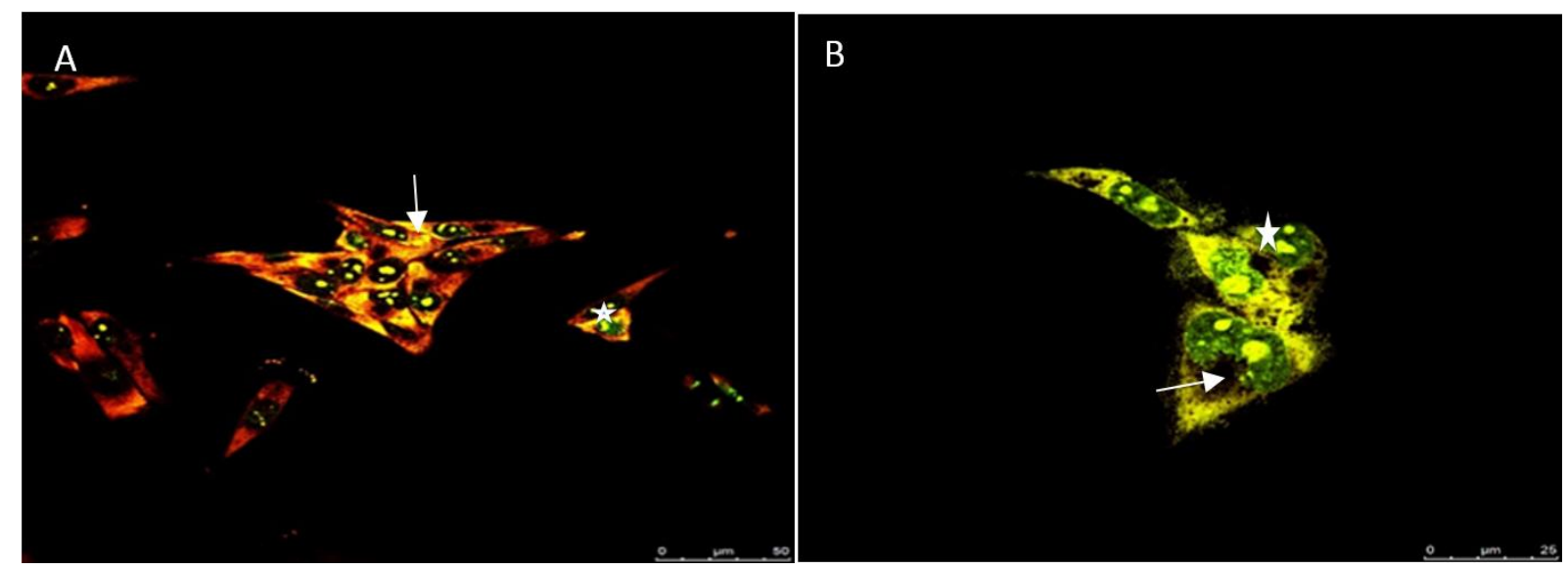

Şekil.3, Hazırlanan hemolenfin Beas-2B hücreleri üzerindeki etkileri. A; kontrol Beas-2B hücreleri: ok-normal hücre iskeleti, yıldı-hücre çekirdeği. B; $\mathrm{IC}_{50}$ konsantrasyonları uygulanmış Beas-2B hücreleri: ok-parçalanmış hücre iskeleti, yıldız-yoğunlaşmış hücre çekirdeği. 


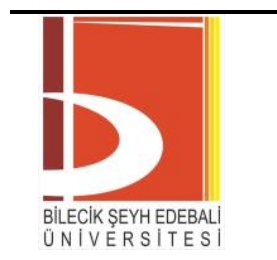

BŞEÜ Fen Bilimleri Dergisi

7. Cilt - Milli Mücadele ve TBMM'nin

BSEU Journal of Science

Açılışının 100. Yı1ı Anısına-100. Yıl Özel

Sayis1

$363-372,2020$

e-ISSN: 2458-7575 (http://dergipark.gov.tr/bseufbd)

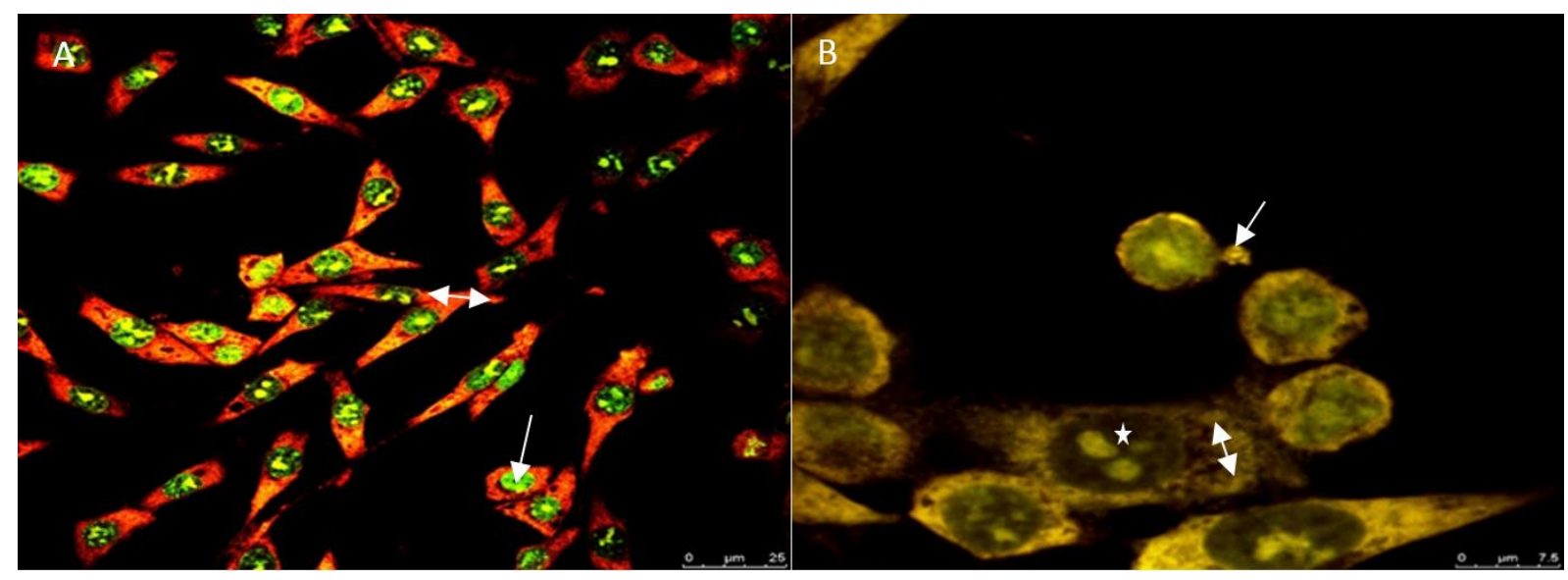

Şekil.4, Hazırlanan hemolenfin A549 hücreleri üzerindeki etkileri, A; kontrol grubu A549 hücreleri; ok-normal hücre çekirdeği, çift yönlü ok-normal hücre iskeleti. B; $\mathrm{IC}_{50}$ konsantrasyonları uygulanmış A549 hücreleri: Ok-membran tomurcuklanması, yıldız-kromatin yoğunlaşması, çift yönlü ok-hücre iskeletinde parçalanma.

\section{Geçirimli Elektron Mikroskop (TEM) Sonuçları}

A549 ve Beas-2B hücre hatları üzerine önceden hazırlanmış akrep hemolenfinin $\mathrm{IC}_{50}$ konsantrasyonları ile inkübe edildikten sonra elde edilen TEM sonuçları aşağıda Şekil 5 ve Şekil 6 ile gösterilmiştir. Şekil 5 A ve 5B ye bakıldığında hücre genel morfolojisinde çok bir değişiklik görülmemektedir. İnce yapısal değişikliklere bakıldığında ise hücre memranındaki tomurcuklanmalar ile apoptoza doğru giden bir hücre profili gözlenmektedir. Şekil 6A ve 6B ile elde edilen sonuçlar kıyaslandığında ise belirgin morfolojik değişiklikler görülmüş̧ür. Hücre çekirdeği kaybolmuş ve lizozomlar artmıştır. Hücre iskeleti bozulmuştur. TEM sonuçları konfokal mikroskop sonuçlarını desteklemektedir.

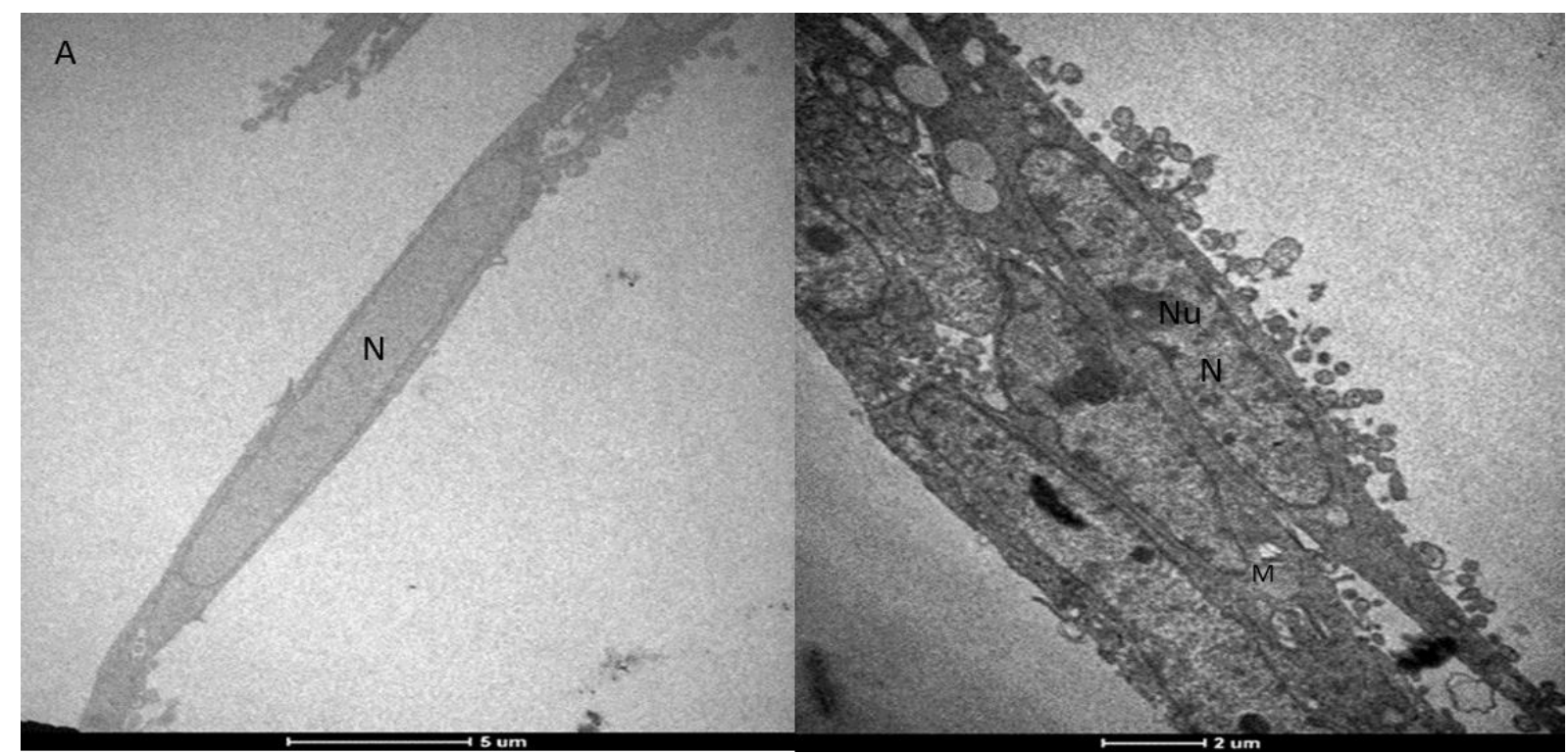

Şekil.5. Hazırlanan akrep hemolenfinin Beas-2B hücreleri üzerindeki etkileri. A; Kontrol Beas-2B hücreleri, B, IC 50 $_{50}$ konsantrasyonları uygulanmış Beas-2B hücreleri. N; hücre çekirdeği, M; mitokondri, Nu: kromatin yoğunlaşması 

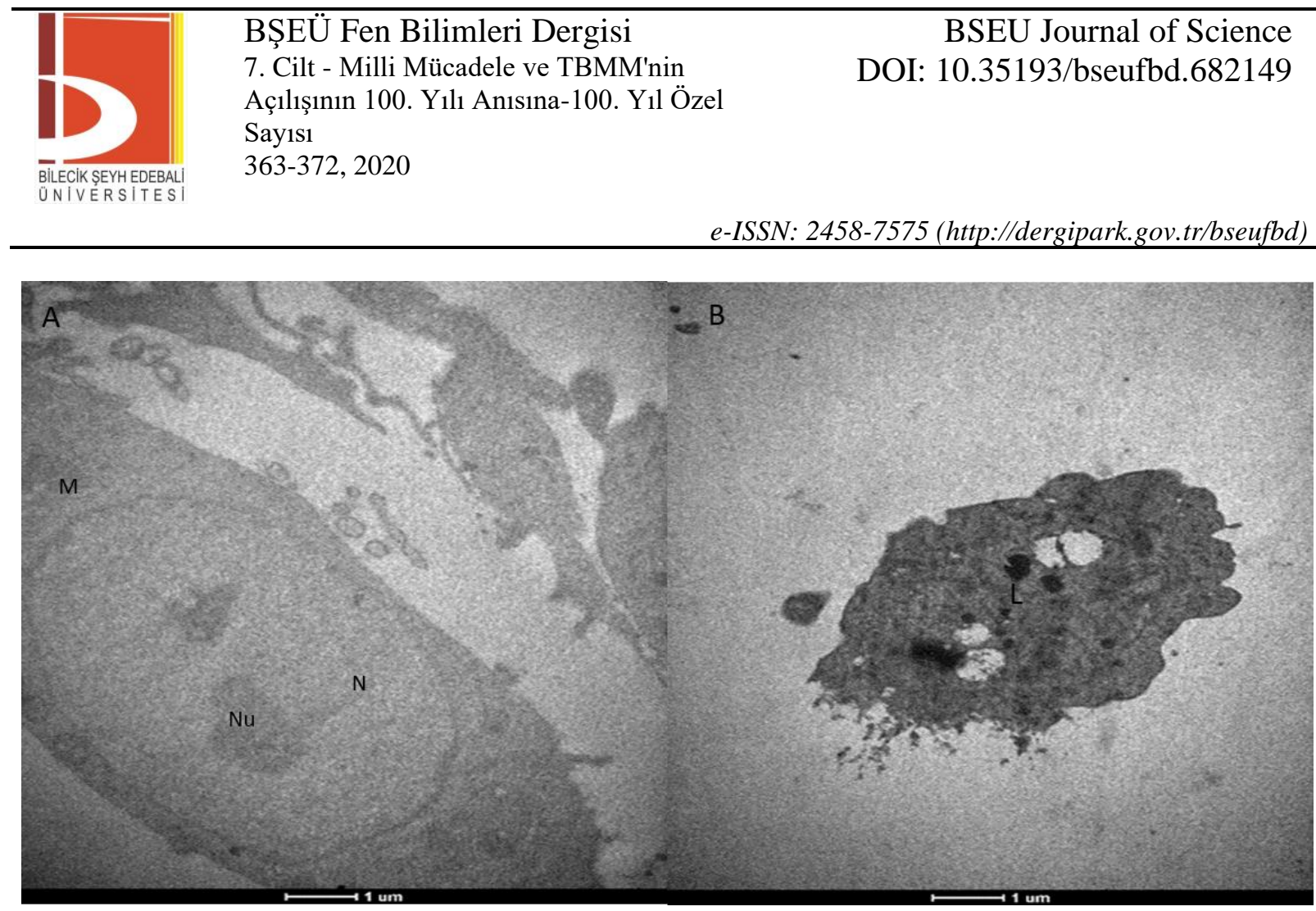

Şekil.6. Hazırlanan akrep hemolenfinin A549 hücreleri üzerindeki etkileri. A: Kontrol A549 hücreleri görüntüsü B: IC $_{50}$ konsantrasyonları uygulanmış deney grubu A549 hücresi. N; çekirdek, M; mitokondri, Nu; kromatin yoğunlaşması, L; lizozom.

\section{TARTIŞMA}

Kanser, gelişmiş ülkelerin tüm çabalarına rağmen halen beş ölümden birine neden olmaktadır. Cerrahi, kemoterapi ve radyoterapi ile gerçekleştirilen tedaviler tam olarak sağlanamadığı için yetersiz koruma sağlamakta ve bu alandaki arayış halen devam etmektedir. Anti-kanser tedavisi araştırmacıları yan etkileri en aza indirebilecekleri sadece kanserli hücreyi hedef alan yeni bir tedavi yaklaşımı arayışı içindedir. Biyolojik ürünler olan venomların, hemolenflerin içerdikleri protein/peptid karışımları ile birçok alanda etkinlikleri gösterilmiş, bazıları ilaç olarak tedavide yerlerini almışlardır [18].

Uluslararası raporlanan hemolenf çalışmaları incelendiğinde Limulus polyphemus (Atnalı yengeci) hemolenfinin başarı ile biyoteknolojik alanlar ve ilaç sanayinde kullanıldığı bilinmektedir. Endotoksin (bakteri gibi patojenlerin içinde bulunan, potansiyel olarak toksik olabilecek bileşikler) varlığını tespit etmek için Atnalı yengeci hemolenfi kullanılmaktadır. İmplante edilecek cihazların patojen varlığını belirlemek için kullanılmaktadır. Dünyada tek kaynak ise bu türün hemolenfidir [19]. Litopenaeus vannamei (Pasifik beyaz karides) ile yapılan çalışmalarda ise hemolenfte bulunan Limpet isimli büyük proteinin insanlarda bir immün yanıtı tetikleyen epitopları olduğu bildirilmiştir [20]. Hemolenfe sahip diğer bir tür olan Erypelma californicum (Tarantula) ile yapılan çalışmalarda hemolenfin anti-mikrobiyal ve anti-fungal etkilere sahip olduğu ortaya konmuştur [21]. B. Januszanis ve arkadaşları Galleria mellonella hemolenfinin içerisindeki 30 kD'dan büyük peptidler ile çalışmalar gerçekleştirmiş ve bu hemolenfin insan beyin glioblastoma multiform T98G hücreleri üzerine apoptotik/nekrotik etkileri olduğunu bildirmişlerdir [22]. Son moleküler çalışmalar, omurgasız fizyolojisinde hemolenf proteinlerinin ve fonksiyonel peptitlerin önemli bir rol oynadığını ortaya koymuştur $[22]$.

Bu çalışmada Mesobuthus gibbosus (Brullé, 1832), akrebinin hemolenfinin anti-kanser potansiyelini araştırmak için sitotoksisite testleri yapılmış ve çıkan sonuçları morfolojik olarak değerlendirmesi gerçekleştirilmiştir. Hazırlanan hemolenf A549 ve Beas-2B hücrelerine farklı konsantrasyonlarda (\%0,31, $\% 0.63, \% 1.25, \% 2.5, \% 5, \% 10) 24$ saat boyunca uygulanmıştır. MTT testi sonuçlarına göre $\mathrm{IC}_{50}$ değeri belirlenmiştir. Elde edilen sonuçlardan, doza bağlı bir şekilde kanser hücrelerine karşı belirgin bir sitotoksisite belirlenmiştir. Ancak, ilginçtir ki normal akciğer epitel hücre hattı Beas-2B'de özellikle \%2.5'den düşük dozlarda poliferatif bir etki gösterirken yüksek dozlarda antipoliperatif etki gözlenmiştir. 
Konfokal mikroskopi kullanılarak elde edilen sonuçlara bakıldığında, hemolenf uygulanmıș hücrelerin görüntüleri ile uygulanmamış hücreler karşılaştırıldığında morfolojik değişiklikler bulunmuştur. Ancak, Beas-2B hücreleri arasındaki morfolojik değişiklikler A549 grubu kontrol ve deney grubu arasındaki morfolojik değişikliklerden daha azdır. Hazırlanmış hemolenf ile muamele görmüş A549 grubu hücreler yuvarlaklaşmış ve membran tomurcuklanması bariz olarak saptanmıştır. Ayrıca hücre çekirdeğinde kromatin yoğunlaşması görüntülenmiştir. $\mathrm{Bu}$ bulgular yine 24 saat $\mathrm{IC}_{50}$ miktarının uygulandığ 1 Beas-2B hücrelerinde de saptanmıştır ancak hücreler normal hücre şekillerini korumuşlardır (Şekil 3B Şekil 4B).

TEM ile gerçekleştirilen görüntülemede akrep hemolenfinin A549 hücreleri üzerindeki ince yapısal etkilerine bakılmıştır. Bu incelemede $\mathrm{IC}_{50}$ dozunda hücre şeklinin bozulmasına ek olarak büzülme gerçekleştiği belirlenmiştir. Hücre içerisinde yer yer hücre iskeletinde yırtıklar ve lizozom oluşumu görülmüştür. Hücre zarlı organellerinde mitokondri kristalarında kayıp ve şişmeler izlenmiştir. Membran bütünlügünün kaybolması apoptotik cisimciklerin görüntülenmesi hücrelerin apoptoza yöneldiğini işaret etmektedir (Şekil 6). Benzer bulgular Beas-2B normal akciğer epitel hücreleri kontrol ve deney grubuna baktığımızda her iki grupta mekik şeklini korumuştur (Şekil 5A, 5B). Ancak deney grubunda kromatin yoğunlaşması ve hücre memranında tomurcuklanmalar da gözlenmiştir.

Bu çalışma ile M. gibbosus türü akrep hemolenfinin A549 ve Beas-2B hücre hatları üzerindeki biyolojik etkisi araştırılmıştır. Hemolenfin bir karışım olması nedeniyle bileşimindeki etken biyoaktif biyomoleküllerin araştırılması ve ileri çalışmalarla saflaştırılarak hücrelere uygulanması durumunda yeni moleküllerin keşfine olanak sağlayacağı düşünülmektedir. Çalışma sonuçları akrep hemolenfinin ilaç sektöründe farmakolojik araçlar olarak kullanılması için aktif moleküller içerdiğini ve daha ileri araştırmalara da ihtiyaç duyulduğunu işaret etmektedir.

\section{KAYNAKLAR}

[1] Rincón-Cortés, C. A., Olamendi-Portugal, T., Carcamo-Noriega, E. N., Santillán, E. G.,Zuñiga, F. Z., ReyesMontaño, E. A. \& Possani, L. D. (2019). Structural and functional characterization of toxic peptides purified from the venom of the Colombian scorpion Tityus macrochirus. Toxicon, 169, 5-11.

[2] Possani, L. D., \& de la Vega, R. C. (2006). R: Scorpion venom peptides. Handbook of biologically active peptides, 1, 339-354.

[3] Carcamo-Noriega, E. N., Possani, L. D., \& Ortiz, E. (2019). Venom content and toxicity regeneration after venom gland depletion by electrostimulation in the scorpion Centruroides limpidus. Toxicon, 157, 87-92.

[4] Ojeda, P. G., Wang, C. K., \& Craik, D. J. (2016). Chlorotoxin: structure, activity, and potential uses in cancer therapy. Peptide Science, 106(1), 25-36.

[5] Moghadam, A. T. (2011). Evaluation of scorpion hemolymph (blood) proteinic pattern by SDSPAGE. Clinical Biochemistry, 13(44), S241.

[6] Guncheva, M., Paunova, K., Ossowicz, P., Rozwadowski, Z., Janus, E., Idakieva, K., ... \& Tzoneva, R. (2016). Rapana thomasiana hemocyanin modified with ionic liquids with enhanced anti breast cancer activity. International journal of biological macromolecules, 82, 798-805.

[7] Wang, X., \& Wang, G. (2016). Insights into antimicrobial peptides from spiders and scorpions. Protein and peptide letters, 23(8), 707-721. 
[8] Hmed, B., Serria, H. T., \& Mounir, Z. K. (2013). Scorpion peptides: potential use for new drug development. Journal of toxicology, 2013.

[9] Upadhyay, R. K. (2010). Animal proteins and peptides: Anticancer and antimicrobial potential. J Pharm Res, 3(12), 3100-3108.

[10] Gomez Rave, L. J., Munoz Bravo, A. X., Sierra Castrillo, J., Roman Marin, L. M., \& Corredor Pereira, C. (2019). Scorpion venom: New promise in the treatment of cancer. Acta Biológica Colombiana, 24(2), 213-223.

[11] Zhang, S. F., \& Chen, Z. (2017). Melittin exerts an antitumor effect on non-small cell lung cancer cells. Molecular medicine reports, 16(3), 3581-3586.

[12] Gopalakrishnakone, P., Cheah, J., \& Gwee, M. C. E. (1995). Black scorpion (Heterometrus longimanus) as a laboratory animal: maintenance of a colony of scorpion for milking of venom for research, using a restraining device. Laboratory animals, 29(4), 456-458.

[13] Alllel, P. M., Dautıgny, A. Lamy, J. Lamy, J.N. Jolles, P. (1983). Cell-Free Synthesis of Hemocyanin from the Scorpion Androctonus australis Characterization of the Translation Products by Monospecific Antisera, Eur. J. Biochem. 134, 407-414.

[14] Fricke, K., Prendini, L. Wirkner, C. S. (2012). Evolutionary morphology of the hemolymph vascular system in scorpions: A character analysis, Arthropod Structure \& Development 41 (2 ) 545-560.

[15] Eroğlu, O. Kaya, H. Celik, E., Celen, M., Korkut, E., and Nizam, N. (2019). Triple Effect of Doxorubicin,5Fluorouracil, Propranolol on Cell Survival on MCF-7Breast Cancer Cell Line. Journal of Biosciences and Medicines, 7,74-85

[16] Çömlekçi, E., Kutlu, H. M., \& Vejselova Sezer, C. (2018). Toward stimulating apoptosis in human lung adenocarcinoma cells by novel nano-carmofur compound treatment. Anti-cancer Drugs.

[17] Çiftçi, G. A., Işcan, A., \& Kutlu, M. (2015). Escin reduces cell proliferation and induces apoptosis on glioma and lung adenocarcinoma cell lines. Cytotechnology, 67(5), 893-904.

[18] Gesheva, V. Chausheva, S. Mihaylova, N. Manoylov. I. Doumanova. L. Idakieva. K. Chorbanov. A.(2014). Anti-cancer properties of gastropodan hemocyanins in murine model of colon carcinoma, BMC Immünol. 29; 15-34.

[19] Walls, E. A., Berkson, J. and Stephen, S. A. (2002). The Horseshoe Crab, Limulus polyphemus: 200 Million Years of Existence, 100 Years of Study, Reviews in Fisheries Science, 10(1): 39-73.

[20] Li, C. Wang, F. Aweya, J.J, Yao, D, Zheng, Z. Huang, H. Li, S . Zhang, Y. ( 2018).Trypsin of Litopenaeus vannamei is required for the generation of hemocyanin-derived peptides Developmental and Comparative Immunology 79 ,95-104.

[21] Schartau, W and Leidescher T (1983) Composition of the hemolymphof the tarantula Eurypelma mifornicum. J Comp Physiol (1983) 152:73-77.

[22] Cytrynska, M. Mak, P. Zdybicka, A. Suder,P. Jakubwicz,T. (2007).Purificaion and characterization of eight peptides from Galleria mellonella immune hemolymph, Peptides 28, 533-546. 